\title{
Modes of Action of Potential Phyto-Pesticides from Tropical Plants in Plant Health Management.
}

\author{
*DN Enyiukwu CC. Ononuju ${ }^{1}$ AN Awurum ${ }^{1}$ JA Nwaneri $^{2}$ \\ ${ }^{1}$ Department of Plant Health Management, Michael Okpara University of Agriculture, Umudike, PMB 7269 \\ Umuahia Abia State \\ ${ }^{2}$ Minor Root Crop Programme, National Root Crop Research Institute (NRCRI) Umudike, P.M.B 7006 \\ Umuahia, Abia State, Nigeria.
}

\begin{abstract}
Presence of toxic natural products in several higher tropical plant species which play roles in warding off pests and pathogenic attacks is well reported in the last couple of years. That these natural products ex situ, infringe metabolic processes and inhibit pests or pathogenic species in culture or field studies are also well documented. However, so far information on how they act against the susceptible species to bring these about, are scarcely available. With the exception of the pyrethrins, nicotine, rotenone and recently neem and its related flora, there is dearth of information on the modes of action of potential pesticides from tropical plants. Recent evidences suggest however, that several potential phytochemicals are enzymes antagonists and/or may interfere with cell membrane integrity, while extracts of Reynoutria spp. primes crops' defense systems against invading fungi. Proper understanding of the modes of action (MOA) of a pesticide will enable plant pathologist not to use phytochemicals with similar MOA sequentially or in combination, and thus delay pests or fungal resistance to the control agent(s). Herein, we present a review of the modes of action of potential plant-derived pesticides; the object being to enable plant health practitioners to maximize the benefits of the use these complementary or alternative pesticides in IPM programmes in order to delay, reduce or eliminate pests or fungal resistance build-up known to be a major drawback associated with use of synthetic chemicals in agricultural pests control.
\end{abstract}

\section{INTRODUCTION}

Statistics from the United Nations Department of Economic and Social Affairs, Population Division in July---2014---showed---that---7.25---billion people currently inhabited the world (m.worldometres.info/worldpopulation/...). This number is projected to rise to 11 billion in 2100 (Carrington, 2014). Human population explosion coupled with increasing urban migration, fewer numbers of farmers, smaller farm sizes and industrialization adversely affected arable crop production. The result is that nearly 1 billion people especially in sub-Saharan Africa and Southern Asia are suffering from severe hunger and starvation (Bill and Melinda Gates Foundation, 2011; Kana et al., 2012).

Several attempts through the green and gene revolutions had been geared at solving the world food problem through adoption of crop species which promised high productivity, product attractiveness and ease of harvesting. Rising economic pressures on the part of farmers encouraged them to plant uniform crop varieties in monocultures. While these revolutions have undoubtedly saved millions from starvation, they have however led to loss of $75 \%$ in genetic biodiversity of cultivated crops; thereby causing a serious threat on food security to ensue (Awake, 2001). Large hectarages of monocultures provide uniform plant cover and food sources liable to attack from crop decimating pathogenic species.

Synthetic fungicides have been employed for control of pathogenic fungi which attack agricultural crops. For example in a study in Tanzania, Dithane M-45 (Mancozeb) controlled brown rust of cowpea and effectively improved its productivity by $65 \%$ (Edema and Adapala, 1994). While in Nigeria, carbendazim and benomyl strongly checked the development and spread of anthracnose and brown blotch diseases induced by Colletotrichum species in the same crop (Emechebe and Florini, 1997).

These successes notwithstanding, issues of high bio-magnification of synthetic pesticides residues in the food chain coupled with consumers' concerns about safety of synthetic fungicides-treated foods have heightened in recent years (Schleier and Peterson, 2011). In addition, excessive and/or inappropriate applications of fungicides have resulted in over 150 pathogenic fungal species to be resistant to once effective chemical control agents (Enyiukwu et al., 2014a). The resistance development in the fungi is thought to be made worse by use of fungicides with same or similar modes of action either simultaneously or sequentially (OHP, 2011). These amongst many factors of their effects on non-target organisms and ecological health, have made plant health management practitioners to seek for user-friendly alternative approaches for pests and pathogenic fungal control, in low input farming systems of sub-Saharan Africa (Amadioha, 2003; Gourounti et al., 2008) or 
organic farms in developed economies of the world. One such alternative that is gaining global attention is use of extracts of higher plants in plant disease control (Enyiukwu et al., 2014b).

Several secondary metabolites have been isolated from aromatic and medicinal plants ranging from phenols, alkaloids, flavonoids, saponins, tannins, glycosides, terpenoids and steroids These compounds are known to play in situ roles in warding off attacks from pathogenic organisms and herbivoury on plants (Enyuiukwu and Awurum, 2013). Beginning from 1763 when nicotine derived from Nicotinia tabacum was used to kill aphids, several plant-based compounds including pyrethrins, rotenone and their related compounds, neo-nicotinoids, and pyrethroids in the intervening years, have found use in agricultural pest management (Enyiukwu et al., 2014a, b).

According to Phosiso (2011) plant-gleaned pesticides use in agriculture at the turn of the millennium, made up $1.2 \%$ of the total plant protection inputs. This, all things being equal, was projected to grow steadily at $15.6 \%$ per annum in the years from 2014 (BccResearch, 2014). Research indicated that azadirachtin (Azadirachta indica), rotenone and its relatives (Tephrosia vogelii), ryanodine and dehydro-ryanodine (Ryania speciosa) cervacine, protocevacine, stilbene and arylbenzofuran glycosides (Schoenocaulon officinale), securine and methyl salicylate (Securidaca longependenculata), verbascoside and calceolariosides (Calceolaria andila) are some of the commercially important plant-derived efficacious metabolites finding application in modern pest management programmes (Kanchanapoon, 2002; Silva-Aguayo, 2015). Others are extracts from Melalueca alternifolia designated for use against black sigaoka disease in plantains and bananas (STK, 2012), and Reynoutria sachalinensis registered as Regalia ${ }^{\circledR}$ for control of walnut blight and cereal pest attacks (OHP, 2011). In addition, citrus oil, quassia, lemon grass, sabadilla, and capsicum have also been approved as phytopesticides in Australia, Hungary, Egypt and Denmark, USA and Mexico respectively (El-Wakeil, 2013).

Nevertheless, comparative to synthetic pesticides however, commercial plant-derived pesticides are still very few in use (El-Wakeil, 2013). Dearth of knowledge on their efficacy with reference to their particular active ingredient(s); toxicity profiles especially on mammals, and modes and/or mechanisms of their action have been suggested as some of the factors militating against their adoption on a global scale (Phosiso, 2011; Enyiukwu et al., 2014a). Of these factors, mode (mechanism) of action of the plant-derived compounds is touted as the most important impediment against their adoption (Enyiukwu et al., 2014b).

This review therefore, stresses the significance of the modes/mechanisms of action (MOA) of plant-derived compounds toward improving the quality of plant protection management in agriculture.

\section{SYNTHETIC PESTICIDES AND THEIR MODES OF ACTION}

Chemical control of plant diseases began with inorganic compounds such as sulphur, fixed copper and Bordeaux mixture. This class of fungicides has broad spectra of activity, affecting a broad array of metabolic activities such as electron transport, membrane permeability and enzyme functions on a wide range of susceptible organisms. Over half a century years ago, organic, surface protectants also called multi-site fungicides such as maneb and captan were introduced. They are grossly effective as seed treatment chemicals and for the control of rots, leaf-spots and other fungal diseases of economic crops. Several fungicides in this category act by generating isothiocyanates against thiol (sulfhydryl) groups in many enzyme systems of fungi and ribosomal RNA synthesis respectively (OHP 2011). In the case of thiabendazole, its mechanism of fungicidal action is still unclear though it is thought to cause inhibition of energy production in the fungus Penicillium atrovenetum by impairing fumarate reductase system, and a variety of mitochondrial enzymes including nicotinamide adenine dinucleotide oxidase (Allen and Gottlieb, 1970; Pronk and Shefferlie, 2015). Their broad spectrum of pesticidal activity spill over as toxic effects on many non-target species and also their residues in treated foods have been implicated in cancers, allergies, birth defects and even death in mammals (Enyiukwu 2002; Enyiukwu and Awurum, 2013a, b). And thus constituting in effect; a major drawback on their use for crop protection (Awurum and Enyiukwu, 2013).

Owing to this therefore, several narrow spectrum systemic benzimidazole fungicides including benomyl, thiophanate-methyl and carbendazim with less deleterious effects on non-target organisms were introduced in the late 1960s. This group of fungicides is translocated through the plant without being broken down by the plant's enzyme systems, maintain selective toxicity on one or related pathogenic fungi, and have wide application post-infection and disease appearance in crops. Inhibition of mitotic cell division and growth through binding to and preventing microtubule formation has been reported as the mode of action of these fungicides on very many pathogenic fungi of agricultural relevance (Ragsdale, 1994; Pscheidt, 2015). However, the narrow spectrum of activity of most systemic fungicides over time caused selection pressure to increase towards resistance development in fungal populations. Scientific reports indicate that at present resistance to a given anti-fungal agent occurs about 7 years post introduction of the fungicide, making it a serious challenge in crop health management (Oreskes and Conway, 2010; Enyiukwu et al., 2014a, b). Tank-mixing or alternating fungicides with different modes of action, is recommended to at least delay build up of resistant fungi in agriculture (Pscheidt, 2015). The modes of action of some fungicides are presented in Table 1. 
Table 1: Modes of action of some synthetic fungicides used in modern/conventional crop protection

\begin{tabular}{|c|c|c|c|c|}
\hline Chemical class of fungicides & $\begin{array}{l}\text { Common } \\
\text { names }\end{array}$ & $\begin{array}{l}\text { Trade } \\
\text { names }\end{array}$ & Primary uses & $\begin{array}{l}\text { Modes of action } \\
\text { (MOA) }\end{array}$ \\
\hline Diakyldithiocarbamates & Thiram & & $\begin{array}{l}\text { Foliar } \\
\text { diseases of } \\
\text { many crops }\end{array}$ & $\begin{array}{l}\text { Inactivates } \\
\text { many enzymes }\end{array}$ \\
\hline Ethelenebisdithiocarbamates & $\begin{array}{l}\text { Maneb, } \\
\text { Zaneb }\end{array}$ & & $\begin{array}{l}\text { Leafspot } \\
\text { diseases of } \\
\text { many crops }\end{array}$ & $\begin{array}{l}\text { Generates } \\
\text { isothiocyanates } \\
\text { which } \\
\text { inactivates thiol } \\
\text { groups in } \\
\text { enzymes and } \\
\text { cell metabolites. }\end{array}$ \\
\hline Quinone & Dichlone & & $\begin{array}{l}\text { Seed } \\
\text { treatment, } \\
\text { controls } \\
\text { diseases of } \\
\text { fruits and } \\
\text { vegetables }\end{array}$ & $\begin{array}{l}\text { Inhibits } \\
\text { electron } \\
\text { transport and } \\
\text { sulfhydril } \\
\text { groups } \\
\text { enzymes. }\end{array}$ \\
\hline Phthalmides & Captan & & $\begin{array}{l}\text { Seed } \\
\text { treatment, } \\
\text { controls } \\
\text { diseases of } \\
\text { fruits and } \\
\text { vegetables }\end{array}$ & $\begin{array}{l}\text { Inhibits } \\
\text { ribosomal RNA } \\
\text { synthesis }\end{array}$ \\
\hline Organostins & triphenyltin & & $\begin{array}{l}\text { Pecan } \\
\text { diseases }\end{array}$ & $\begin{array}{l}\text { Inhibition of } \\
\text { oxidative } \\
\text { phosphorylation } \\
\text { and impairment } \\
\text { of energy } \\
\text { production }\end{array}$ \\
\hline Carboximides & Carboxim & & $\begin{array}{l}\text { Grain } \\
\text { diseases }\end{array}$ & $\begin{array}{l}\text { Electron } \\
\text { transport } \\
\text { inhibition. }\end{array}$ \\
\hline Benzamidazoles & $\begin{array}{l}\text { Benomyl, } \\
\text { carbendazim,- } \\
\text { thiabendazole, } \\
\text { thiophanate- } \\
\text { methyl. }\end{array}$ & & $\begin{array}{l}\text { Many } \\
\text { diseases on a } \\
\text { wide range } \\
\text { of crop }\end{array}$ & $\begin{array}{l}\text { Inhibits tubulin } \\
\text { formation in } \\
\text { MAP mitosis. }\end{array}$ \\
\hline Pyrimidines & propiconazole & $\begin{array}{l}\text { Banner }{ }^{\circledR} \\
\text { Strider }{ }^{\circledR}\end{array}$ & & $\begin{array}{l}\text { Demethylation } \\
\text { inhibitors, } \\
\text { inhibition of } \\
\text { sterol synthesis }\end{array}$ \\
\hline Dicarboximides & Iprodione & & $\begin{array}{l}\text { Diseases of } \\
\text { vegetables, } \\
\text { fruits and } \\
\text { ornamentals }\end{array}$ & $\begin{array}{lr}\text { Not specific--, } \\
\text { thought } \\
\text { impair to } \\
\text { division }\end{array}$ \\
\hline Phenylamides & Metalaxyl & & $\begin{array}{l}\text { Black pod of } \\
\text { cocoa, } \\
\text { diseases } \\
\text { caused by } \\
\text { Oomycetes }\end{array}$ & $\begin{array}{l}\text { Inhibits } \\
\text { ribosomal RNA } \\
\text { synthesis. }\end{array}$ \\
\hline
\end{tabular}

Sources: Ragsdale, 1994; OHP, 2011

Some fungicides can attack plant cell membranes. Membranes are selectively permeable boundaries found inside the cell wall and around cell organelles. They present functional and barrier properties and participate in many cellular processes including transport of chemicals, oxidative phosphorylation and biosynthesis (Ragsdale, 1994). It is hence the point of serious attack of some classes of fungicides. For example, the carbamate fungicide Propamocarb, is reported to act by attacking and disrupting cell membrane 
permeability in susceptible fungi, causing loss of electrical coordination, ataxia and death of the affected fungus (OHP, 2011).

\section{MODE OF ACTION OF BIO-AGENTS}

Use of natural enemies of pests and pathogens such as Trichoderma sp., Gliocladium sp., Bacillus thurngiensis and Baculoviruses has been advanced as one of the eco-friendly alternatives for managing challenges from crop attacking pests and pathogens in the farm and storage (Enyiukwu et al., 2014a). Bacillus thuringiensis (Bt) is used for control of insect pests of agricultural crops. In affected insects; loss of appetite, food abandonment, paralysis were commonly observed symptoms, with death finally ensuing. In the guts of the lepidopteron pests, the enzymes-activated $\mathrm{Bt}$ toxins bind to specific receptors (cadherin-like proteins, peptidases, alkaline phosphatase) located in the insects' microvilli. The Cry-toxins then perforate the intestinal walls, and cause vacuolation of the cytoplasm, leading to cells disruption, and death of the affected insect (Shunemann et al., 2014). In a recent evaluation, conducted on maize farms in Nigeria, atoxigenic isolates of Aspergillus flavus (Alfasafe ${ }^{\circledR}$ ) significantly controlled aflatoxin contamination in the crop with nearly a $100 \%$ success recorded from the trials (Bandyopadhyay et al., 2007). In another study on palm tree (Elias guineensis) the devastating black seed rot of sprouted seedlings and dry basal rot of adult palm trees caused by Ceratocystis paradoxa was also efficiently checked by Trichoderma viride and metabolites from its relatives $T$. polysporum, T. hamatum and T. aureoviride. The bio-agent likewise, effectively retarded the growth of Fusarium oxysporium, Rhizoctonia solani, Curvularia lunata and Alternaria zinnia (Eziashi et al., 2007)

The antagonists were observed to entwine around the fungus $C$. paradoxa, penetrated its hyphae and conidia, and distorted its metabolism, leading to death of the pathogen. The actual mechanism of action of these antagonistic saprobes on these crop decimating species is not thoroughly understood yet; but it has been suggested to involve hyper-parasitism, and secretion of toxic volatile and non-volatile anti-biotic compounds such as trichodermin, trichodermol, harzianum A and hazianolide against the pathogens (Eziashi et al., 2007). However, besides the constraints presented by dearth of knowledge on their modes of action, Enyiukwu et al. (2014b) reported that formulating and presenting these bio-agents in such a way that low-input farmers making up the large numbers of growers of different crops in sub-Saharan Africa can apply them is still elusive.

\section{MODE OF ACTION (MOA) OF PLANT-BASED PESTICIDES: A HIGHLIGHT}

Several classes of pyhto-chemicals have been identified from different plant families ranging from alkaloids, tannins, saponnins, flavonoids, steroids, glycosides and terpenoids. The biological activities of plant materials are underpinned by one or more of these phyto-chemicals. The mode of action (MOA) of a phyto-pesticide refers to the specific biochemical interaction between the active ingredient of a phyto-pesticide and the target organism leading to its reported effects on the pathogens. Phyto-chemicals are allelochemicals. They affect cellular molecular targets in susceptible organisms including bio-membranes, infringe signal transduction at the bio-membranes by interfering with ion channels and ion pumps; and neurotransmitter receptors such as noradrenaline, GABA, acetylcholine, seratonine; messenger enzymes of signal pathways or microtubule formation. Some may interfere with DNA, RNA and protein synthesis (Wink, 1998). For these reasons many plant materials are finding application as botanical pesticides in agriculture.

The first generation botanicals consist of extracts rich in pyrethrins, nicotine and rotenone. Pyrethrins are lipophillic 3-carbon esters coupled to 5-carbon aromatic alcohols; and usually soluble in organic solvents. They are derived from the flower heads of the daisy plant Tanacetum cinerariefolium (Chrysanthemum cinerariefolium). This crop was grown in considerably large commercial quantities in Kenya, Tanzania, Rwanda, Japan and Ecuador (Schleier and Peterson, 2011).

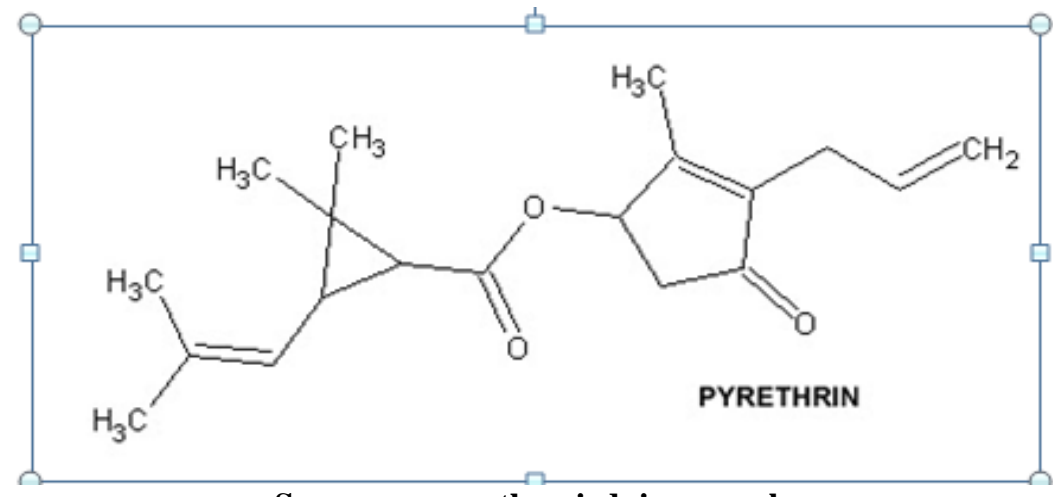

Source: www.the-piedpiper.co.uk 
Six kinds of compounds \{Ppyrethrins $1 \& 11(70 \%)$, cinerins $1 \& 11(19 \%)$ and jasmolins 1 \& 11 $(8 \%)\}$ which may exist in trans- or cis forms make up the active principles of the daisy flower heads with pyrethrin 1 being the most abundant (Hassan, 1990; Schleier and Peterson, 2011; El-Wakeli, 2013). This Tanacetum-derived pesticide is used in fogging cocoa and other agro-produce against moths (Ephestia cantella), and has been reported to exhibit effective protectant fungicidal effects against crop attacking fungi and molds. As a result, they can be injected, infused, coated or externally applied on seeds, as well as on below and above ground parts of economic crops in IPM or organic farming programmes (Kumar, 1986; Wageningen University, 2015). In addition modifying agricultural crops with genetic capacity to synthesize pyrethrins for improved resistance against a wide array of pests and diseases had been advocated (Enyiukwu et al., 2014b; Wageningen University, 2015). Pyrethrins also find good application in environmental and public health control of zoonotic pests such as lice, fleas and mosquitoes (Hassan, 1990). Its pesticidal activity is characterized by strong and rapid knock-down effects especially in insects. These compounds (pyrethrins) like rotenone and its related compounds are also toxic to aquatic lives. However, they have been reported to exhibit extremely low toxicity to warm blooded animals such as mammals. Pyrethrins are extremely unstable to UV radiation which causes up to $20 \%$ reduction in its activity per year. High cooking temperatures, as well as digestive and/or enzyme systems of affected pests hydrolyse the poison by acid or base catalyzed mechanisms such that they recover from the knockdown paralysis after a short time (Hassan, 1990). For this reason they are formulated as wettable powders, dusts and synergized aerosols. Pyrethrins are neurotoxic poisons known to modulate sodium ions and voltage-gated sodium channels in a similar manner to organo-chlorines. The poison disallows the closing of these channels. In mammals pyrethrin 11 participate in depleting noradrenaline stores which culminates in writing convulsions. Toxicity of pyrethrins in affected organisms generally presents symptoms of hyperexcitability, prostration, convulsions and finally death. It is reasoned that the mechanism of pyrethrins action may involve to a lesser extent, disruption of membrane pumps that participate in calcium ion dependent ATPase, and calcium/magnesium ion dependent ATPase in different biological contexts on different receptors like GABA-gated, and voltage sensitive chloride and calcium channels and peripheral benzodiazepine receptors which enhanced the uncontrolled tremors (Schleier and Peterson, 2011).

Nicotine and nornicotine are another important pesticidal compounds gleaned from Nicotiana tabacum and $N$. rustica both members of the Solanaceae (Kumar, 1986). They are closely related to anabasine which is obtained from the plants of the family Chenopodiaceae. These compounds occur as viscious liquids which darken upon exposure to light. Conventionally for long term action, they are formulated to salts of appropriate solubility such

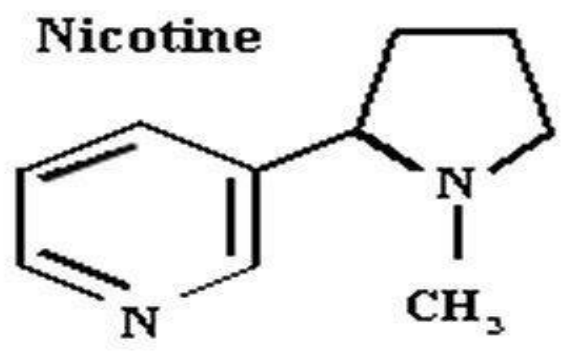

Source: www.Scott.net

as nicotine sulphates and nicotine tanates. This formulation is necessary because nicotine is photo-labile, being broken down by photo-energy. Antibacterial activities of the compound to a wide spectrum of pathogens, including Kliebsiella pnueumoniae, Escherichia coli, Viridians streptococci and mycobacterium phlei is are documented (Parvia et al., 2000; IFOAM, 2015). Several workers have also demonstrated the efficacy of nicotine in fungal disease control. For instance in Nigeria, Taiga $(2009 ; 2011)$ used it to control postharvest rot of yams caused by Fusarium oxysporium, Aspergillus niger, Rhizopus stolonifer and Penicillium oxalicum. Nicotine and its related compounds are extremely lethal and fast-acting nerve toxins agonistic to acetylcholine. Synthethic copies of nicotine include less toxic imidacloprid, thiocloprid, nitempiram, acetamiprid and thiamethoxam. They are reported to act by mimicking acetylcholine binding to acetylcholine receptors in the nervous system causing synaptic blocking and continuous firing of affected nerves. This presents such symptoms as ganglionic stimulation which types into central nervous failure and death of the affected fungus (Hassan, 1990). However, their extreme toxicity to humans $\left(\mathrm{LD}_{50} 50 \mathrm{mg} / \mathrm{kg}\right)$ and rapid dermal absorption constituted major impediments to their adoption which has largely caused a to a large extent a decline in their use in crop protection and production (EL-Wakeili El-Wakeil, 2013; Silva-Aguayo, 2015). 
Rotenone is a crystalline ketone isoflavonoid and a strong fish poison, originally obtained from the roots of species of Derris (D. elliptica, D. involuta) and Lonchocarpus \{L. urucu (Babasco), L. utilis (lancepod)\}. In Latin America, Peruvian natives used root extracts of the ube plant for stunning fish. Subsequently, rotenone has been isolated from several members of the plant family such as Tephrosia virginiana (Hoary pea) T. vogelii, Pachyrhizus erosus (Mexican yambean, Jicama) Sphenostylis stenocapa (African yam bean), Mundula sericea (Cork bush), Piscidia piscipula (Florida fish poison tree) Dalbergia spp (African Blackwood) and Millettia laurenti.

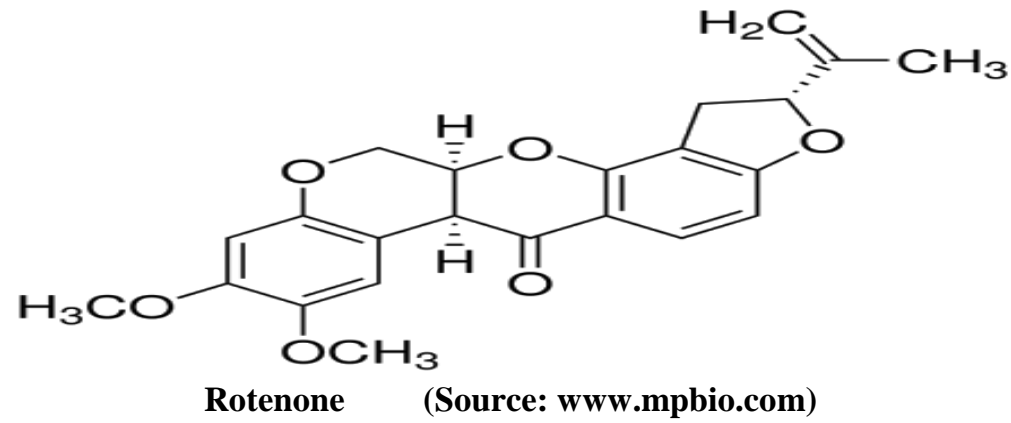

This lipophilic compound is classified as extremely toxic to insects and aquatic lives ( $\left.\mathrm{LC}_{50} 20-40 \mathrm{ppb}\right)$ but moderately toxic to birds and mammals; its association with Parkinson's disease (PD) in humans has been reported in literature (Ott, 2015). In advanced economies, use of rotenone in lakes for removal of unwanted fishes is a common environmental management practice. Further toxic action to aquatic life in such situations is stopped by addition of 1-5 ppb potassium permanganate solution to the lake. This plant-derived pesticide reportedly acts by electron transport inhibiton at cytochrome $b$, denying cells of utilizing tissue oxygen, with cell death eventually ensuing (Enyiukwu et al., 20134a, Ott, 2015). The mechanism of this action (MOA) is linked to the inhibition of the transfer of electrons from iron-sulphur centers in complex 1 to ubiquinone in the mitochondia. This spills into interference with nicotinamide adenine dinuleotide (NADH) during the creation of energy in the form of cellular adenosine triphosphate (ATP). Thus creating a back up of electrons within the mitochondrial matrix which leads to reduction in cellular oxygen to radical, and inducing a reactive oxygen species (ROS) which then damages DNA and other components of the mitochondria; which action is closely related-to-apostasis-in - experimental-animals $\quad(\mathrm{Li} \quad$ et $\quad$ al., www.inchem.org/documents/pims...7.1\%20\%20Mode\%20of\%20Action; Li et al., 2002;). Though rotenone is considered of low toxicity in humans, strong suspicion exists of it being the underlying cause of Parkinson's disease (Sherer et al., 2003)

In like manner, Tephrosia spp. (belonging to the family Fabaceae) and native to Africa, India and tropical parts of Austrialia is a potent phytopesticide. Over 300 species make up the genus of which T. nana is used as a rodenticide while T. uriflora is employed as molluscicide against the snail (Bulinus globus) vector of schistosomiasis. Others such as T. bracteole, T. candida, T. densifora, T. noctifora, T. pedicellata and T. vogelii are potent fish poisons ( $\mathrm{LC}_{50} 0.002-0.2 \mathrm{mg} / \mathrm{liter}$ ) used by natives of Bangladesh, Ivory Coast, Congo and Nigeria for fish stunning. In ethno-medicine, health practitioners employ Tephrosia spp. to treat diarrhea, tuberculosis, syphilis, and localized fungal infections. Leaves, stems, fruit coats and roots of the plants have been used as rodenticide, insecticide, anthelmntic, abortifacient and for induction of menses in human females. Tephrosia vogelii (Igbo: Iwele) is a much branched shrub cultivated in middle belt of Nigeria. The plant thought to have originated in Angola; is a source of biologically active principles consisting of rotenone, rotenolone, deguelin, tephrosin, quercitin, vogeloside, stigmasterol, lanosterol, elliptone, and rutin which collectively are called rotenoids (Denza et al., 2007). Anti-larvicidal and insecticidal activities of acetone extracts of Tephrosia sp. against Aedes aegypti and Pieris rapae respectively have been documented. Rotenoids' mechanism of pesticidal action occurs through infringing the energy production of affected organisms by interfering with electron transport process between reduced diphosphopyrodine nucleotide or reduced nicotinamide adenine dinuleotide (NADH) and cytochrome b in the mitochondria (Denza et al., 2007).

In a trial in Southeast Nigeria, Annona squamosa leaf extracts strongly impeded Colletotrichum spp. on cowpea (Chukwu, 2010). From chemical fractionation bioassays, Annona squamosa and A. muricata seed extracts afforded the toxic compound annnonin 1 . The fungitoxic activity of this compound is reported to be by blocking energy production of affected pathogens at the mitochondria (El-Wakeil, 2013). Toosendanin from Melia toosendan and meliacarpin gleaned from Melia azedarach with their closely related compound azadirachtin obtained from Azadirachta indica have been used in many control programs against crop pathogens. Amadioha and Obi (1998) and Amadioha (2003) checked the decimation of cowpea in field studies with aqueous extract of neem, while rot of both yam and cassava tubers in storage was control with organic and water extract of neem as well (Okigbo, 2004; Amadioha and Markson, 2007a, b; Obi, 2011). In the case of affected insects, these triterpenoid compounds are tooted reported to disrupt ecdystic hormonal balance 
(prothoracicothrophic hormone, PTTH) preventing molting and growth; by insect anti-feedant, repellant activities (Brown, 2006) as well inhibiting cytosolic enzymes of mycotoxigenic species through antioxidantrelated activity (Da Costa et al., 2010).

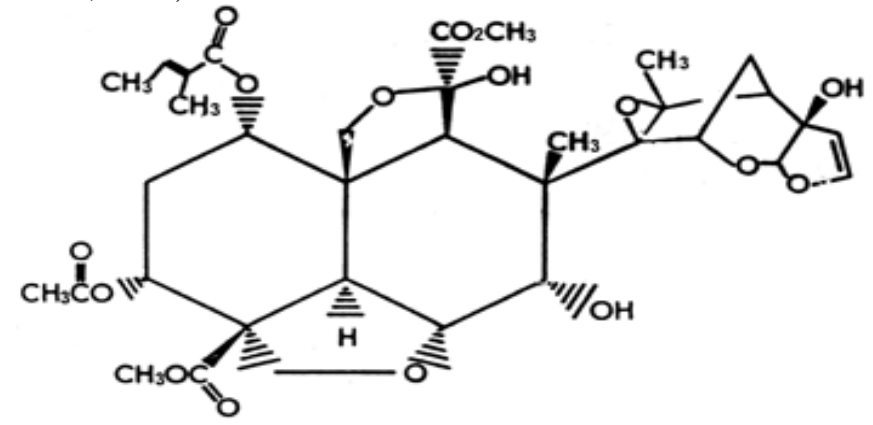

Azadirachtin Source: Silva-Aguayo, 2015

Similarly Citrus spp. peels rich in the neurotoxin product D-limonene, effectively impeded Sclerotium rolsii cause of basal stem rot of cowpea (Okwu and Njoku, 2009). The mechanism of action of this toxin is reported to involve heightening spontaneous activity of sensory cells.

Ryanodine, dehydro-ryanodine and ryanodol are present in Ryania speciosa (Facourtiaceae). Ryanodine the chief of the alkaloids, is a stomach poison which interferes with calcium release, and prevents muscle contraction, leading to death in the affected organisms (Brown 2006; El-Wakeil 2013, Silva-Aguayo, 2013). The mechanism of this action is reported to involve binding to channels in the sarcoplasmic reticulum of muscle, allowing $\mathrm{Ca}^{2+}$ to flow into the cells, resulting in cell death (Opender and Dhallwal, 2003). A summary of the modes of action (MOA) of some first and second generation phyto-pesticides are given below in Table 3 .

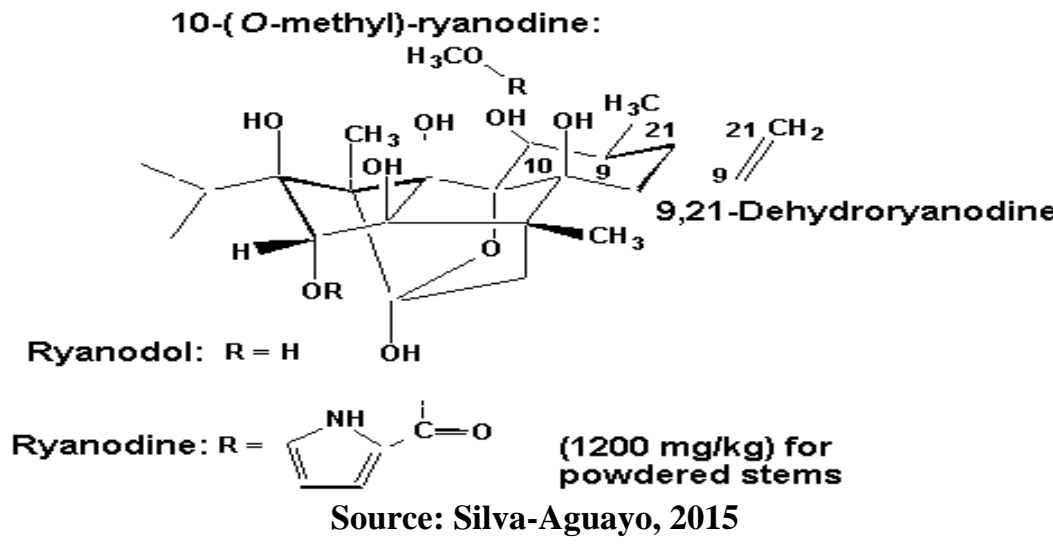

Table 3: Mechanism of action of some plant-derived pesticidal compounds

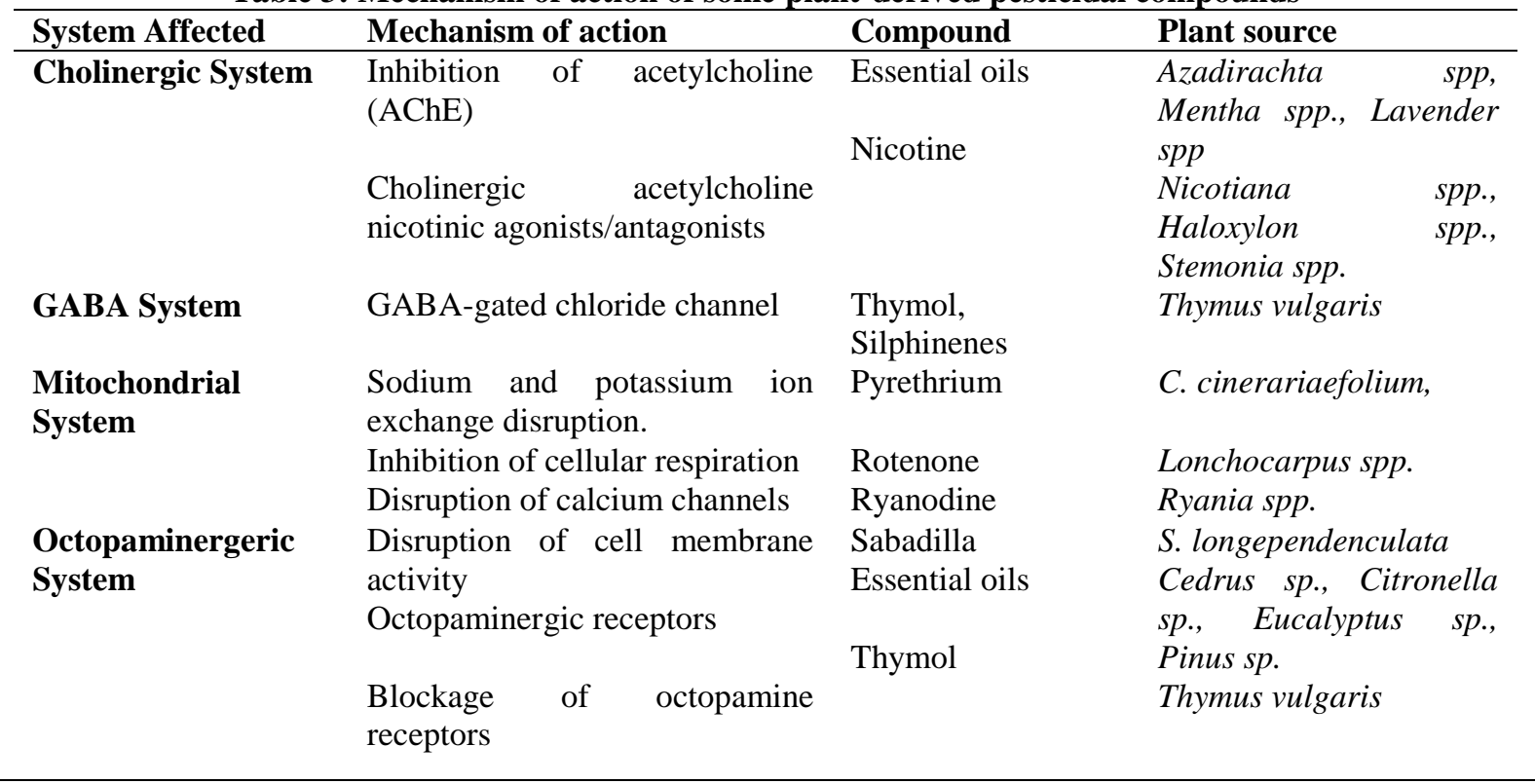


Sabadilla (Schoenocaulon officinale) a member of the family Liliaceae, contain many seeds-derived alkaloids cevadine and its close relative veratridine. These alkaloids upon hydrolysis with alkaline yield cevacine (cevine) and protocevacine (cevadillin) which have been reported as the active principles of the extracts (Kupchan et al., 1953; Kanachanapoon, 2002; Greive, 2015). Though the later hydrolytic isolate is more toxic than the former (Greive, 2015), both act by disrupting neuron cell membrane bringing about reduction of nerve activity, symptomised by paralysis and death of susceptible organisms (Silva-Aguayo, 2015). The mechanism of this action involves preferentially binding to activated sodium channels, which results to increased nerve excitability. In addition stilbenes a class of phenolics commonly found in members of the Vitaceae, are also important isolates from S. officinale (Kanachanapoon, 2002). They bring about extensive membrane damage in fungal cells. This is reported to lead to suppression of exogenous respiration which causes insufficient uptake of food. Evaluations of the stilbeenes resveratrol (3,5,4'-trihydoxystilbene) and perostilbene (3,5,-dimethoxy4 'hydrostilbene) on Botrytis cinerarea caused a significant decrease in oxygen uptake in the fungus and inhibition of its conidial respiration respectively (Pevet and Pont, 2003). Their efficacy is thought by these authors to depend on lipophilicity and on ability of the compounds to penetrate fungal cell wall and membranes. Incorporation of methoxy- or hydroxyl- groups or long alkyl chain substituents on the position 4 of the resveratrol analogues were confirmed by Chalal et al. (2014) to improve the lipophilicity of the stilbenes in cellular environments and enhanced their trans-membrane penetration and anti-fungal activities.

Antifeedant, antioxidant, antibacterial, antimicrobial and trypanocidal activities have been ascribed to extracts from members of the genus Calceolaria. As an instance, $C$. andila contains diterpenes, phenylpropanoids and napthoquinones which play roles in the inductive and constitutive defense mechanisms of the plant. Fractionation of its extracts afforded verbascoside, calceolariosides A,B,C and D; 2-(1,1dimethylprop-2-enyl)-3-hydroxy-1,4-naphtoquinone and its close acetone derivative 2, acetoxy-3-(1,1dimethallyl)-1,4-nathoquinone (Cespedes and Salaza, 2013). The naphtoquinone compounds were implicated for the insecticidal activity of the extracts against agricultural insect pests by Kambay et al., 1999. These leafderived pesticidal compounds have been patented by BTG Internatinal Ltd and are reported to be known enzyme and metabolic inhibitors, affecting different target sites on the enzymes and different molecular targets on metamorphosis processes of susceptible organisms (Cespedes and Salaza, 2013).

Reynoutria sachalinensis (Regalia ${ }^{\circledR}$, Milsana ${ }^{\mathrm{TM}}$ ) is a commercially available plant product registered as protectant fungicide for use in the greenhouse against mildew of wheat; walnut, cucumber, tomato and other crops. An evaluation of Reynoutria sachalinensis extract against powdery mildew by Daarf (1995) on long English cucumber showed that it adequately prevented the development of the disease and effectively protected the physiology of the plant leaf. The phyto-pesticide had shown activity in inhibiting the conidial germination of another fungus Leveluilla taurica. Chemically, the extract afforded the amphipathic anthraquinone compound phys-cion with carbonyl molecules which is present in the green component of the alcohol extract. Though its mode of action against fungi is not thoroughly understood yet, it is thought to induce host plants' defense mechanism through stimulating and boosting chitinases production, phytoalexin synthesis, papilla formation, vacuolization of infectious haustoria, reactive oxygen species (ROS) and enzyme phenolic pathways (Lehnhof, 2007). However, some authorities do not accept the theory involving stimulation of hypersensitivity and production of phytoalexins as a possible mode of action of the compound (Kowalewski, 1993). Macleaya cordata (Bloodroot) contains the alkaloids sanguinaine and chelerythrine both of which had exhibited insecticidal and fungicidal properties. Their retardation of growth and development of Rhizoctonia solani for example has have been reported. As with the foregoing phyto-fungicide Regalia ${ }^{\circledR}$, the mode of action of these alkaloids is unclear; but seem to be by priming the systemic resistance of the host plant through upgraded synthesis and release of phenolic compounds (Mi-Young et al., 2013).

Securidaca longepedenculata (The violet tree) (polygalaceae) is a shrub or small tree, that grows in African woodlands and savannas savanannas. The plant is used in ethno-medicine for the treatment of inflammations, arthritis, fever, diabetes, infertility, constipation, tuberculosis, gonorrheoa and several microbial infections. It is also used for treating mental disorder, snake bites and evil spirits troubled persons and fish poison. Haruna et al. (2013) confirmed the antimalarial efficacy of methanol root extracts of the plant against Plasmodium berghei in laboratory animals. The plant root powder when mixed with the methanol stem bark extracts are used for making arrow poison. With respect to crop protection, African farmers use the powder obtained from the root and bark to make low-cost pesticide which kills all weevils in grains stored in jars within 5-6 days. According to Stevenson et al. (2009) the root extract of this plant when mixed with cowpea or maize extensively reduced the numbers of Sitophillus zeamais and Callosobruchus maculatus for up to 9 months postinfection. The preparation was found to be anti-oviposition, repellant and toxic to both larvae and the adult 
parasites. Anti-fungal efficacy of ethanol leaf extract of the shrub against mycotoxigenic Aspergillus flavus and A. niger has been demonstrated (Jinadu et al., 2014). These investigators also reported from phyto-chemical screenings the presence of alkaloids, flavonoids, tannins, saponins, glycosides, anthraquinones and volatile oils in the plant material. The roots are rich in the volatile compound methyl salicylate $(90 \%)$ which confers insect repellency and mortality on the extract (Jayasekara et al., 2005). Upon fractionation Stevenson et al. (2009) reported, the yield of the bioactive bisdesmosidic saponins securines A and B also from the root; however these compounds are more abundant in the twigs and barks of the plant's above ground parts. In addition, polymethoxy-xanthones, were also isolated from the chloroform extracts of $S$. longepedunculata by Fita et al. (2013) which compounds preferentially exhibited pancreatic cancer cells death by apostasis in humans.

Adenium obesum (Chalcals baobao) (Apocenaceae) is one of the most toxic plants of Africa occurring in the savannas of Senegal to Nigeria. It finds several applications in traditional medicine of the savanna dwellers and is also used in combination with other herbs for making arrow poisons (Sho, 2015). Stem powders in veterinary medicine are used for control of ecto-parasites of camel and cattle as well as lice and fleas in livestock. The extracts' use in crop protection for control of cotton bollworm (Helioptis sp.) spring bollworm (Earias sp.) and the Sudan bollworm (Diparopsis wartei) by eastern Senegalese farmers have been documented. Methanol stem extracts of the plant inhibited Escherichia coli, Neissiera gonorrhea, Klebsieella pneumonia, Salmonella typhii and Pseudomonas aereginosa in a trial and phytochemical probes revealed the presence of anthraquinones, tannins, flavonoids, saponins and glycosides in the plant material (Tijjani et al., 2011). Bioassay-guided fractionation of the extracts from the plant by Versani et al. (2014) afforded Pregnanes and triterpenoid amongst other chemical isolates. So far however, information on the mode(s) of action of these compounds is grossly unavailable.

Polyphenolics, one of the major natural product constituents of tropical flora, occur on surfaces or in the cytoplasmic fraction of the epidermal cells in fruits, seeds, nuts, stems, leaves and flowers. They are substances which constitute one of the most common groups of compounds in plants with a wide range of biological activity. They act as deterrents to fungal invasion of plant tissues. Conventionally, polyphenolics possess antioxidant activity; and may also play roles in protecting the plant against UV- $\beta$ radiation (Cushite and Lamb, 2005; Ferrazzano et al. 2011). In a study Harbourne (2000), noted that flavoniods and polyphenols have widespread ability to inhibit spore germination of plant pathogens. The plant Artemesia giraldi afforded 6,7,4 ${ }^{1}-$ trihydroxy- $3^{1} 5^{1}$-dimethoxy flavones and $5,5^{1}$ - dihydroxy $0-8,2^{1}, 4^{1}$ - trimethoxy flavones together with $5,7,4^{1}$ - trihydroxy $3^{1} 5^{1}$ - dimethoxy flavones. These compounds have been reported to exhibit antifungal activity against the recalcitrant dry rot fungus Aspergillus flavus (Harbourne, 2000).

Several theories have been propounded for the mechanisms of action of many present day potential phyto-pesticides. For example, Melaleuca alternifolia extract's (Timorex Gold®) impressive antifungal activity against the fungus Mycospharella fijiensis the cause of black sigatoka disease corroborated this assertion (STK, 2012). According to them, Timorex Gold ${ }^{\circledR}$ destroyed cellular integrity, increased membrane permeability in cell structures, caused loss of cytoplasm and inhibited respiration and ion transport process in the affected fungus. According to Adeshina et al. (2010), ethyl acetate leaf extract of Alchornea cordifolia inhibited clinical isolates of Escherichia coli, Staphylococcus aureus, and Candida albicans with 100\% rate of kill of the organisms after $2 \mathrm{~h}$. The antimicrobial action of A. cordifolia leaves against these organisms was ascribed to the alkaloid isopentenyl guanidine (Lamikara et al., 1990). In another study, Okwu and Ukanwa (2010a) indicated that anthocyanide glycosides isolated from leaves of A. cordifolia also inhibited these human pathogens. However, the mechanisms of action of the antimicrobial chemical isolates are not thoroughly known; though disruption of cellular integrity and enzyme inactivation has been proposed and advanced by Okwu and Ukanwa (2010a;b). Some of the theories propounding or estimating the mechanism of action of antimicrobial activity of potential phyto-pesticides are highlighted below.

\section{INHIBITION OF CYTOPLASMIC MEMBRANE FUNCTION}

Inhibition of germ tube formation as well as mycelia conversion has been reported in the fungus Candida spp. by lipophillic components of Melaleuca alternifolia and Eucalyptus globules (Noumi et al., 2010; 2011). These investigators suggested that this antifungal action was due to impairment of fungal membrane integrity and function. From propidium and salt tolerance tests, Tomlinson and Palombo (2005) concluded that leaves of Eromophila dutoni compromised the intergrity of cytoplasmic membrane structures of $S$. aureus. They also thought that this resulted from distorted permeability of the cytoplasmic membrane leading to increased uptake of propidium iodide and decrease in the ability of the bacterial tissues to exclude sodium chloride. A congruent report by Ferrazzano et al. (2011) supporting this assertion, remarked that the mechanism of action (MOA) of catechins a class of polyphenols on bacterial rods including Pseudomonas, aeruginosa, Salmonella sp. etc was due to generation of hydrogen peroxide which altered the permeability of the microbial cell membranes and 
interfering with bacterial quorum sensing. Similarly, Shimamura et al. (2007) reported that epigallocatechingallate (EGCg) from green tea binds to peptidoglycans - an essential component of cell walls of Staphylococcus aureus rods and induce its precipitation. This compound may also interfere with its biosynethic function and these were adduced as the major reasons for inhibition of the pathogen. Cushine and Lamb (2005b) showed that tea-derived EGCg damaged bacterial cell membranes by perturbing the lipid bilayers, penetrating them and disrupting the bacterial functions or possibly by membrane fusion leading to leakage of intra-membraneous materials and aggregation. These researchers showed that $S$. aureus rods exposed to the flavonoid galangin lost $25 \%$ more potassium ions $\left(\mathrm{k}^{+}\right)$than the control experiments; and thus, further buttressing buttressed the cell damage and loss of radicals' theory.

\section{INHIBITION OF ENERGY METABOLISM}

Lico-chalcones A and C gleaned from the roots of Glycyrrhiza inplata is thought to inhibit S. aurreus and Micrococcus luteus by impairing their oxygen uptake and respiration. This was believed to be consequent from effective inhibition of of the enzyme NADH-cytochrome reductase, involved in energy production between sites COQ and cytochrome-C (Haragueli et al., 1998). Similar report by Salvatone et al. (1998) showed that recently the flavanone lonchocarpol A inhibited macromolecular synthesis in Bacillus megaterium perhaps by antagonizing RNA, DNA, and protein synthesis; leading ultimately to impaired energy metabolism.

\section{INHIBITION OF CRITICAL ENZYMES}

Furanocoumarins and sphingolipids were isolated from extracts of Ficus spp. and curcumin and eucalyptol from Curcumin longa. Extracts of these plant materials had previously shown strong anti-fungal activities against Aspergillus flavus, A niger, A. fumigatus, Fusarium oxysporium, F. solani, Penicillium oxalicum P. chrysogenum, P. digitatum Rhizopus stolonifer, and Botrydiplodia theobromae causing rot of yam tubers in storage in the tropics (Adebayo et al., 2009; Parveen et al., 2013). This fungitoxic activity the investigators suggested was may to be due to impairment of a variety of enzymes involved in energy and structural syntheses of the rot and/or mycotoxigenic fungi. Shimamura et al. (2007) in a parallel study reported that EGCg from green tea, binds to penicillin binding proteins ${ }_{2}\left(\mathrm{PBP}_{2}\right)$ and inhibit its enzymatic action. Against the pathogen Staphylococcus mutans Ferrazzano et al. (2011) revealed that polyphenols exerted anti-enzyme activity, inhibiting glycosyl transferase and amylases. It has been suggested that the mechanism of enzyme inhibition of eukaryotic enzymes may be due to interaction of the enzyme with phenyl ring, phenol and benzopyrone ring of the flavoniod (Cushine and Lamb, 2005a). Aside of these actions, Wang and Stoner (2008) suggested that polyphenols may also chelate heavy metals present in enzymes structural architecture, and thereby inactivate them.

\section{INHIBITION OF NUCLEIC ACID SYNTHESIS}

According to Mori et al., (1987) DNA synthesis was strongly inhibited by flavonoids in Proteus vulgaris whilst RNA synthesis inhibition was most pronounced in Staphylococcus aureus by myricetin and epigallocatechin. These tea-derived flavoniods provoked intercalation or hydrogen bonding with stacking of nucleic acid bases, thus impeding RNA and DNA synthesis. Ohemeng et al. (1993) observed that quercitin, epigemin and 3,6,7,3 $3^{1}, 4^{1}$-pentahydroxy-flavones inhibited Escherichia coli, S. aureus, S. epidermidis and S. typhimirium DNA gyrase. The enzyme activity inhibition by quercitin as noted by Hillard et al. (1995) was due to bonding to GyrB subunit of $E$. coli and hence binds the enzyme ATpase activity (Plaper et al. 2003).

\section{a. SUGGESTED MODES/MECHANISMS OF ACTION OF SOME POTENTIAL PHYTO-PESTICIDES.}

The efficacy of plant-derived pesticides against a wide spectrum of microorganisms inciting field and storage diseases in plants is well documented (Amadioha, 2003; Enyiukwu et al., 2014a, b). And that phytoextracts are rich in a wide range of plant-based bio-active chemical compounds that infringe growth and development of the incitants and inhibit the initiation of myco-induced diseases is also well reported in literature (Enyiukwu et al., 2014b). As instances, curcuminoids (curcumin, demethoxycurcumin and bisdemethoxycurcumin) compounds toxic to Colletotrichum spp., have been isolated from Curcumin longa rhizomes. Similarly, Piper longum afforded the piperidine alkaloid pipernonaline to which Rhizoctoniaa solani and Phytophtora infestans are strongly sensitive (Usman et al., 2009; Enyiukwu and Awurum 2013; Mi-Young et al., 2013). Though the active ingredients (a.i) of the phyto-extracts may have been isolated, and the relative positions of their functional groups on the skeleton of the active ingredients determined. However, pertinent questions as to how they bind to, impede, retard growth or kill pests or pathogens remain largely unanswered in most cases. And where they exist, they are probable estimates predicated on the chemical structures of the active ingredients (a.i) of the plant compounds. For example, Okwu and Ukanwa (2010b) estimated from studies on structural elucidation of chemical isolates, that the antimicrobial activity of Bridelia ferugina Benth was due to 
impairment of a variety of enzymes and membrane disruption. Some postulations on the modes of action of some plant-derived pesticides are presented in Table 1. A recent review therefore remarked that the mode/mechanisms of action of most potential phyto-pesticides are not thoroughly understood as yet. For instance, the mode of action of the phyto-fungicide Regalia ${ }^{\circledR}$ (Reynoutria sachalinensis) is so far unclassified (OHP, 2011). While that for Cinnacure ${ }^{\circledR}$ (Cinnamonium zeylanicum) is still uncertain. Researchers though, think that Cinnacure ${ }^{\circledR}$ impairs respiration, glucose uptake and energy metabolism of susceptible pathogens (Brown, 2006). There is in a general sense, dearth of information on the mechanism of action of many of the potential new generation plant-derived pesticides (Enyiukwu et al., 2014a, b)

Table 1: Modes of action suggested for the antimicrobial activity of some tropical medicinal plants useable as potential phyto-pesticides.

\begin{tabular}{|c|c|c|c|c|}
\hline Organism(s) & Compound(s) & Plant(s) & $\begin{array}{l}\text { Estimated } \\
\text { Mode(s) of } \\
\text { Action (MOA) }\end{array}$ & Source \\
\hline $\begin{array}{ll}\text { Aspergillus } & \\
\text { flavus, } & A . \\
\text { fumigatus, } & P . \\
\text { digitatum, } & F . \\
\text { oxysporium, } & F . \\
\text { moniliformes. } & \end{array}$ & $\begin{array}{l}\text { Curcumin, } \\
\text { demethoxy- } \\
\text { curcumin, } \\
\text { tumerone, } \\
\text { Eucalyptol, } \\
\text { pinene }\end{array}$ & $\begin{array}{l}\text { Curcumin longa } \\
\text { Linn. }\end{array}$ & $\begin{array}{lr}\text { Impairment } & \text { of a } \\
\text { variety } & \text { of } \\
\text { enzymes } & \\
\text { involved } & \text { in } \\
\text { energy } & \text { and } \\
\text { structural } & \\
\text { synthesis } & \end{array}$ & $\begin{array}{l}\text { Parveen et al., } \\
\text { 2013; Usman et } \\
\text { al., 2009 }\end{array}$ \\
\hline $\begin{array}{l}\text { Aspergillus } \\
\text { flavus }\end{array}$ & $\begin{array}{l}\text { Essential oil, } \\
\text { Azadirachtin }\end{array}$ & $\begin{array}{l}\text { Azadirachta } \\
\text { indica } \mathrm{L} \text {. }\end{array}$ & 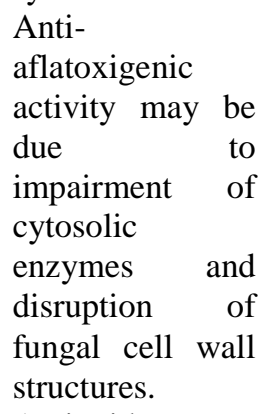 & Da Costa et al. \\
\hline $\begin{array}{l}\text { Kleibsiella spp., } \\
\text { Pseudomonas sp }\end{array}$ & $\begin{array}{l}\text { Flavonoid } \\
\text { chalcones, } \\
\text { anthocyanidines }\end{array}$ & $\begin{array}{l}\text { Bridelia ferugina } \\
\text { Benth }\end{array}$ & $\begin{array}{l}\text { Antioxidant } \\
\text { activity, singlet } \\
\text { oxygen } \\
\text { quenchers, } \\
\text { enzyme } \\
\text { inhibition }\end{array}$ & $\begin{array}{l}\text { Okwu and } \\
\text { Ukanwa, 2010a }\end{array}$ \\
\hline $\begin{array}{l}\text { Proteus mirabilis, } \\
\text { Pseudomonas } \\
\text { aureginosa, E. } \\
\text { coli, Kleibsiella } \\
\text { pneumonia }\end{array}$ & $\begin{array}{l}\text { Anthocyanidine } \\
\text { glycosides }\end{array}$ & $\begin{array}{l}\text { Alchornea } \\
\text { cordifolia }\end{array}$ & $\begin{array}{l}\text { Interference with } \\
\text { cell membrane } \\
\text { integrity, } \\
\text { disruption of cell } \\
\text { structural } \\
\text { synthesis, } \\
\text { impairment of } \\
\text { various enzymes }\end{array}$ & $\begin{array}{l}\text { Okwu and } \\
\text { Ukanwa, 2010b }\end{array}$ \\
\hline $\begin{array}{lr}\text { Candida } & \text { krusei, } \\
\text { Bacillus } & \text { sp., } \\
\text { Albidia } & \text { sp. } \\
\text { Leshmania } & \\
\text { amazonnensis }\end{array}$ & Xanthones & $\begin{array}{l}\text { Allanblackia } \\
\text { gabonensis stem } \\
\text { bark }\end{array}$ & $\begin{array}{l}\text { complexing } \\
\text { nucleophillic } \\
\text { amino acids } \\
\text { irreversibly, \& } \\
\text { protein } \\
\text { inactivation }\end{array}$ & $\begin{array}{l}\text { Azebaze et al., } \\
2008\end{array}$ \\
\hline $\begin{array}{l}\text { Bacillus sp., E. } \\
\text { coli, } \\
\text { Enterococcus } \\
\text { faecalis }\end{array}$ & $\begin{array}{l}\text { Anthocyanins, } \\
\text { Ursolic acids, } \\
\text { neomyrtillin }\end{array}$ & $\begin{array}{l}\text { Vaccinium } \\
\text { myrtillus }\end{array}$ & $\begin{array}{l}\text { Inhibitions of } \\
\text { prostacyclin } \\
\text { synthesis, } \\
\text { gluthathione S- } \\
\text { transferases, } \\
\text { heme-oxygenase } \\
1\end{array}$ & $\begin{array}{l}\text { Plant Profiler, } \\
2010\end{array}$ \\
\hline $\begin{array}{l}\text { Streptococccus } \\
\text { mutans }\end{array}$ & $\begin{array}{l}\text { Magnolol, } \\
\text { Honokiol }\end{array}$ & $\begin{array}{l}\text { Magnolia } \\
\text { officinalis bark }\end{array}$ & $\begin{array}{l}\text { Inhibition of GIT } \\
\text { activity }\end{array}$ & $\begin{array}{l}\text { Ferrazzano } \\
\text { al., } 2011\end{array}$ \\
\hline
\end{tabular}


Modes of Action of Potential Phyto-Pesticides from Tropical Plants in Plant Health Management.

\begin{tabular}{|c|c|c|c|c|}
\hline Candida albicans & $\begin{array}{l}\text { Parnafungin A \& } \\
\text { B }\end{array}$ & ----- & $\begin{array}{l}\text { Bindng and } \\
\text { inactivation } \\
\text { polyadenosin } \\
\text { polymerase } \\
\text { (PAP) }\end{array}$ & $\begin{array}{lll}\text { Adams } & \text { et } & \text { al } \\
2008 & & \end{array}$ \\
\hline $\begin{array}{l}\text { Epidermophyton } \\
\text { floccosum }\end{array}$ & Polygodial & $\begin{array}{l}\text { Drymis } \\
\text { brasiliensis }\end{array}$ & $\begin{array}{l}\text { Structural } \\
\text { disruption of cell } \\
\text { membranes }\end{array}$ & $\begin{array}{l}\text { Malheiros et al., } \\
2005\end{array}$ \\
\hline
\end{tabular}

Emerging scientific findings from a study on the pathogen $S$. mutans, suggest however, that the mechanism of action of most potential phyto-pesticides is thought to involve interaction with microbial membrane proteins and inhibition of critical enzymes such as glycosyl transferase and amylases. Investigators in Nigeria and India found that Meloidogyne incognita attacking legumes such as soybean and cowpea was sensitive to phytochemicals derived from Iconia lotufolia, Uvaria spp., Luffa cylindrical, Stachypheta cayenensis, Carica papaya, Vernonia amygdalina, Syzygium aromatic, Piper betle Acorus calamus and Nicotiana tabacum (Adegbite, 2011). The extracts impeded the nematode egg hatching, reduced the number of galls on infected roots and population of the parasite in the rhizosphere of the crops (Ononuju and Kpadobi, 2008; Wirathno et al., 2009; Ononuju and Ezenwa, 2011). The toxicity of Nicotinia tabacum, S. aromaticum, P. betle and A. calamus were reported superior to the synthetic nematicides chloropyrifos, carbosulfan and deltamethrin by the Indian scientists (Wirathno et al., 2009). Though the mode of action of these plant materials were not studied by the workers, a similar evaluation had found exposure of active nematodes to extracts from Thymus vulgaris, Punica granatum and Artemisia absinthium for $72 \mathrm{~h}$ to effect a $100 \%$ reduction of the nematode activity. This reduction of nematode activity was linked to cholinesterase toxicity of the plant materials against the parasite (Korayem et al. 1993).

The enzymes pectin methyl esterase (PME), polygalacturonase (PG) and pectate lyase (PL) are crucial to haustorial formation, fungal penetration, invasion and colonization of susceptible plant tissues (Dean and Timberlake, 1989; Lewis et al., 2008). These enzymes have been reported to be employed by Rhizoctonia bataticola during invasion and maceration of potato tuber tissues (Amadioha, 1997; 1998; 2004) and cowpea tissues by Colletotrichum dematium (Pakela, 2003; 2006). For instance, Lewis et al., 2008 concluded from gel medium assays that green tea component EGCg strongly impeded both pure and citrus pathogen-gleaned PMEs. Hosts' resistance to pathogenic attack was traced to strong inhibition of these cuticle and cell wall degrading enzyme at the plant's tissue surfaces by the investigators; while loss of virulence of the rot causing bacterium Erwinia carotovora was attributed to loss of synthesis of polygalacturonase.

\section{CONCLUSION}

Reports of the modes/mechanisms of action (MOA) of the crude or isolated phytochemicals are scarcely available. Attempts to establish the possible mode(s) of action of these phytochemicals from selected medicinal plants against target pathogens' membrane structures and permeability, critical enzymes (cholinesterase, PMEs, pectin lyase (PL,) and other metabolic processes of the causal pathogen of plant diseases such as mitotic structures and energy production should be vigorous pursued in the recent times. Accurate knowledge of the MOA of a pesticidal compound based on the understanding of the toxicity of the compound to metabolic processes in affected pathogens; will enable plant pathologists not to use compounds with same or similar MOA simultaneously or sequentially, and thus aid to prevent or at least delay development and build up of resistance of pathogens to the pesticide products. In the overall, this will in turn help plant pathologist to improve the quality and sustainability of plant health management practice in the tropics.

\section{REFERENCES}

[1] Adam, G. C., Parish, C. A., Wisnienski, D., Meng, J., Liu, M., Calati K., Stein, B. D., Athanasopoulos, J., Liberator, P., Roemer, T., Harris, G., and Chapman, K. T. (2008). Application of affinity selection/mass spectrometry to determine the structural isomer of parafungins responsible for binding polyadenosine polymerase. J. Am. Chem. Soc. 130: 16704-16710.

[2] Adegbeti, A. A. (2011). Effects of some indigenous plant extracts as inhibitors of egg hatch in root knot nematode (Meloidogyne incognita race 2). Amer. J. Expt. Agric. 1(3): 96;-100.

[3] Allen, P. M. and Gottlieb, D. (1970). Mechanism of action of the fungicide Thiabendezole, 2-(4'thiazolyl) benzamidasole. Appl. Microbiol. 20(6): 919-926.

[4] Amadioha A. C. and Obi VI 1999. Control of anthracnose disease of cowpea by Cymbopogon citratus and Ocimum gratissimum. Acta Phytopathologica et Entomologica Hungarica 34 (1-2): 85-89. 
[5] Amadioha A. C. and Obi VI 1998. Fungitoxic activity of extracts from Azadirachta indica on Colletotrichum lindemuthianum in cowpea. J. Herbs, Spices, Medicinal Plants 6(): 33-40.

[6] Amadioha, A. C. (1998). Cellulolytic enzyme production by Rhizoctonia bataticola. Arch. Phytopath. Pflanz 31: 415-421.

[7] Amadioha, A. C. (1997). Interaction of hydrolytic enzymes produced by Rhizoctonia bataticola during rot development. Acta Phytopathologica et Entomologica Hungarica 32(1-2): 79-87.

[8] Amadioha, A. C. (1998). Cellulotic enzymes production by Rhizoctonia bataticola. Arch. Phytopath. Pflanz. 31: 415-421.

[9] Amadioha, A. C. (2003). Evaluation of some plant leaf extracts against Colletotrichum lindemuthianum in cowpea. Acta Phytopathologica et Entomologica Hungarica 38: 259 - 265.

[10] Amadioha, A. C. and Markson, A. A. (2007a).Postharvest control of cassava tuber rot caused by Botrydiplodia acerina using extracts--of plant origin. Archives of Phytopathology 40(5): 359 - 366.

[11] Amadioha, A. C. and Markson, A. A. (2007b).Control of storage rot of cassava tuber caused by Rhizopus oryzae using some plant extracts. Archives of Phytopathology 40(6): $381-388$.

[12] Awake, 2001: Is man destroying his own food supply. In: Can we grow enough food? Brooklyn USA, Watchtower Publ. Sept.22, 2001, 003-014.

[13] Awurum, A. N. and Enyiukwu, D. N. (2013).Evaluation of the seed-dressing potentials of phytochemicals from \Carica papaya and Piper guineense on the germination of cowpea (Vigna unguiculata L. Walp) seeds and incidence of the seed-borne fungi. Continental Journal of Agricultural Science 7(1): 29-35.

[14] Azebeze, A. G. B., Ouahouo, B. M. W., Vardamides, J. C., Valentin A., Kuete,V., Acebey, L., Beng, V. P., Nkengfack, A. E. and Meyer, M. (2008). Antimicrobial and antileshmanial xanthones from stem bark of Allanblackia gabonensis (Guttiferae). Nat. Prod. Res. 22(4): 333-341

[15] Bandyopadhyay R., Kumar, M., Leslie, J. F.. (2007). Relative severity of aflatoxin contamination of ceareals in West Africa. Food Additives and Contaminants 24 (10): 1109-1114.

[16] BccReasearch (2014). Global biopesticides market. wwww.bccresearch.com/mobile/market-researcreport/chemicals/biopesticidesmarket-chm029c.html

[17] Brown, A. E. (2006). Mode of action of insecticides and other related pest control chemicals for production agriculture, ornamentals and turf. Pesticide education and assessment program. http://pesticide.umd.edu Retrieved May 30, 2012.

[18] Carrington, D (2014). World population to hit 11 billion in 2100 - with $70 \%$ chance of continuous rise. In: The Guardian, September 18, 2014. www.theguardian/environment/world-population...

[19] Cespedes, C. L. and Salaza, J. R. (2013). Chemical and biological activities of Calceolaria spp. (Calceolariceae: Sprophulariaceae). Phytochem. Res. 10: 1-17.

[20] Chukwu, K. C. (2010). Effects of some plant extracts on plant pathogenic fungi of stored agricultural crops. A Thesis submitted to the Department of Plant Health Management, MOUAU Michael Okpara University of Agriculture Uumudike. November, 2010.

[21] Cushnie, T. P. and Lamb, A. J. (2005a). Antimicrobial activity of flavonoids. Int. J. Antimicrobial Agents 26: 343-356.

[22] Cushnie, T. P. and Lamb, A. J. (2005b). Detection of galangin-induced cytoplasmic membrane damage in Staphylococcus aureus by measuring potassium loss. J. Ethnopharmacol. 101: 243-248.

[23] Da Costa, C. L.,Geraldo, M. R. C., Arroteia, C. C. and Kelmmelmeier, C. (2010). In vitro activity of neem oil [Azadirahta indica A. juss (Meliaceae)] on Aspergillus flavus growth, sporulation, viability of spores, morphology and aflatoxins B1 and B2 production. Adv. Biosci. Biotechnol. 1; 292-299.

[24] Daarf, F. (1995). The effects of plant extracts of Reynoutria sachalinensis on powdery mildew development and leaf physiology of long English cucumber. Plant Dis. 577-580.

[25] Dean, R. E. and Timberlake, W. E. (1989). Production of cell wall degrading enzymes by Aspergilus nidulans: a model system for fungal pathogenesis. The Plant Cell 1: 265-273.

[26] Denza, T., Ayo, J. O., Adelaiye, A. B. and Adaudi, A. O. (2009). Ethno-medicinal and veterinary uses of Tephrosia vogelii Hook. F. A review. Nig Vet. J. 28(3): 23-39.

[27] Duru, C. M. and Mbata, T. I. (2010). The antimicrobial activities and phytochemical screening of ethanolic leaf extracts of Hedranthera bateri Hook and Tabernaemontana pachysiphon Stapf. J. Dev. Biol. Tissue. Eng. 2(1): 001-004.

[28] Edema, R. and Adipala, E. (1994). Cowpea diseases (1 and 2). Control of false smut and brown rust in Uganda using benomyl and mancozeb. East Afr. Agric. J. 60(1): 11-17.

[29] El-Wakeil, N. E. (2013). Botanical pesticides and their modes of action. Gesunde Pflanzen 65(4): 125179.

[30] Emechebe, A. M. and Florini, D. A. (1997). Fungal and bacterial diseases of cowpea. In: Singh, R. S., Morgan-Raj,Daswell, K. E. and Jackai, L.E.N (Eds). Advances in Cowpea Research. IITA Pp 176-183. 
31. Enyiukwu, D N., Awurum, A. N., Ononju, C. C and Nwaneri, J. A. (2014a). Significance of characterization of secondary metabolites from higher plants in phyto-disease management: A review. International Journal of Advanced Agricultural Research. 2: 8-28.

32. Enyiukwu, D. N., Awurum, A. N. and Nwaneri, J. A. (2014b). Efficacy of plant-derived pesticides in the control of myco-induced postharvest and storage rots of tubers and agricultural products: A review. Net Journal of Agricultural Science 2(2): 30-46.

33. Enyiukwu, D. N. and Awurum, A. N. (2013a). Fungitoxic principles and antifungal activity of extracts from Carica papaya and Piper guineense on Colletotrichum destructivum. Continental Journal of Biological Sciences 6(1): 29-36.

34. Enyiukwu, D. N. and Awurum, A. N. (2013b). Fungitoxic effects of Carica papaya and Piper guineense extracts against Colletotrichum destructivum in the glasshouse. Continental Journal of Agricultural Sciences 7(1): 23-28

35. Eziashi E. I., Omamor, I. B. and Odigie, E. E. (2007). Antagonism of Trichoderma viride and effects of water soluble compounds from Trichoderma species and benlate solution on Ceratocystis paradoxa. Afr. J. Bioechnol. 6(4): 388-392.

36. Ferrazzano, G. F. Amato, I., Ingenito, A., Zarrelli, A., Pinto, G. and Pollio, A. (2011). Plant polyphenls and their anti-cariogenic properties: A review. Molecules 16: 1486-1507

37. Fita, D. F., Suresh, K., Shigetoshi, K., Hiroyuki, M. and Yashishiro, T. (2013). Hepta-oxygenated xanthones as anti-austerity agents from Securidaca longepedunculata. www.science.gov>topicpages >longepedunculata...[Abstr.] Accessed June 2, 2014.

38. Gourounti, K., Lykeridou, K., Protopapa, E. and Lazaris, A. (2008). Mechanisms of actions of organochlorine substances. Health science Journal 2(2): 89-98.

39. Grieve, M. (2015). Sabadilla (Veratrum sabadilla; Family: Lilliaceae). www.botanical.com/botanical/mgmh/s/sabadi01.htmlBotanical.com Accessed June 2, 2014.

40. Gurjar, M. S., Ali. S., Akhtar, M. and Singh, K. S. (2012). Efficacy of plant extracts in plant disease management. Agricultural Sciences 3(3): 425-433.

41. Haraguichi, H., Tanimoto, K., Tamura, Y., Mizutani, K. and Kinoshita, T. (1998). Mode of antibacterial action of retrochalcones from Glycyrrhiza inflata. Phytochemistry 48: 125-129.

42. Harborne, J. B. and Williams, C. A. (2000). Advances in flavones research since 1992. Phytochemistry 55: $481-504$.

43. Haruna, Y., Kwanashie, H.O., Anuka, J. A. Atawodi, S. E. and Hussain, I. M. (2013). In vivo antimalarial activity of methanol root extract of Securidaca longepedunculata in mice infected with Plasmodium berghei. Int. J. Modern Biol. Med. 3(1): 007-016.

44. Hillard, J. J., Krause, H. M., Benstein, J. I. (1995). A comparative of active binding site of 4-quinolones and novel flavones gyrase inhibitors of DNA gyrase. Adv. Exp. Med. Biol. 390: 59-69.

45. Jayasakera, K., Stevenson, P. C., Hall, D. R. and Belman, S. R. (2005). Effects of volatile constituents from Securidaca longepedunculata on insect pest of stored grain. J. chem.. Ecol. 31(2): 303-313.

46. Junaidu, S. Shehu, K., Aliero, A. A., Bawa, J. A. and Suleiman, I. (2014). Evaluation of antifungal and phytochemical properties of violet tree (Securidaca longepedunculata Fres). Global J. Sci. Frontier Res. C: Biol. Sci. 14(5):001-007.

47. Kana, H. A., Aliyu, I. A., and Chammang, H. B. (2012). Review on neglected and unader-utilized root and tuber crops as food security in achieving the millennium development goals in Nigeria. Journal of Agriculture and Veterinary Sciences 4: 27-33.

48. Kanchanapoon D (2002). Chemical composition of Schoenocaulon officinale. www.cpb.pharm.org.jp/cpb/.../c06-0863.pdf

49. Khambay, B. P, Batty, D, Cahill, M, Denholm, I, Mead-Briggs M, Vinall, S, Niemeyer, H. M, Simmonds, M. S. (1999). Isolation, characterization and biological activity of naphtoquinones from Calceolaria andina. J. Agric. Food Sci. 47: 770-775.

50. Korayem, A. M., Hasallo, S. A. and Ameen, H. H. (1993). Effects and mode of action of some plant extracts on certain plant parasitic nematodes. Anz. Shadlingske, planfenshuts, Umwetshutz 666: 32-36.

51. Kowalewski, A. (1993). Investigations about the chemical nature and the mode of action of the resistance inducing ingredient from Reynoutria sachalinensis. In: Fritig, B. and Legrand, M. (Eds) Mechanism of Plant Defence Responses. Klumer Academic press, Pp 182.

52. Krisha, P. V. and Lakshma, O. B. (2010). Antibacterial activity of black pepper (Piper nigrum L.) with special reference to its mode of action. Int. J. Nat. Prod. Res. 1(2):213-215.

53. Kupchan, S. M. Lavis, D, Deliwala, C. Vand Andoh, B. Y. A. (1953). Schoenocaulon alkaloids 1: Active principles of Schoenocaulon officinale, cevacine and protocevacine. J. Am. Chem. Soc. 75 (22): 55195524 Pubs.acs..org/doi/abs/10.102/ja611189617. 
54. Kurade, N. P., Jaitak, V., Kaul V. K., Sharma, O. P. (). Chemical composition and antibacterial activity of essential oils of Lantana camara L. Ageratum conizoides and Eupatorium adenophorum. Pharm. Biol. 48(5): 539-544.

55. Lehnohof,, F. (2007). Mode of action of Milsana - Biofa a Reynoutria sacchalinnensis based-plant extract for preventive control of powdery mildews. www.abim.ch/file admin/edu.../.../t_lehnhof_abim_2007./df Retrieved June 8, 2015

56. Lewis, K. C., Shashar, C. and Tworowski, I. S. (2008). Inhibition of pectin methyl esterases activity by green tea catechins. Phytochem. 69: 2586-2592.

57. Malheiros, A. Filho V. C. Schmitt, C B., Yunes, R. A. Escalante, A. Svetaz, L. Zacchino, S. and Monache, F. D. (2005). Antifungal activity of drame sequiterpenes from Dimys brassilensis using bioassay-guided fractionation. J. Pharm Pharmaceut, Sci. 8(2): 335-339.

58. Mi-Young, Y., Byeongjin, C., Jin-Cheil, K. (2013). Recent trends in studies on botanical fungicides in agriculture. Plant Pathol. 29(1): 1-9.

59. Mori, A., Nishino, C., Enoki, N. and Tavata, S. (1987). Antibacterial activity and mode of action of plant flavonoids against Proteus vugaris and Staphlococcus aureus. Phytochemistry 26: 2231-2234.

a. $\quad$ nidulans: A model system for fungal pathogenesis. The Plant Cell 1: 268-273.

60. Noumi, E., Sinousi M., and Bakhrouf, A. (2010). In vitro effects of essential oils of Melaleuca alternifolia and Eucalyptus globulus on mycelia formation by oral Candida albicans strains. Afr. J. Microbiol. Res. 4(12): 1332-1336.

61. Noumi, E., Sinousi M., Halaoui, H., Trabelsi, N., Ksouri, R.,Valentin, E.and Bakhrouf, A (2011). Chemical composition and antifungal potential of Melaleuca alternifolia (Tea tree) and Eucalyptus globulus essential oils against oral Candida species. J. Med. Plants Res. 5(17): 4147-4156

62. Obi, V. I. (2011). Evaluation of four botanical fungicides and situational review on Vigna unguiculata L. Walp. Anthracnose pathogen Colletotrichum spp. Sacc. and Mang. MSc. Thesis, Universidad de Zaragoza, September, 2011.

63. Ohemeng, K. A., Schwender, C. F., Fu, K. P. and Barret, J. F. (1993). DNA gyrase inhibitory and antibacterial activity of some flavones (1). Bioorg. Med. Chem. 3: 225-30.

64. OHP (2011). Chemical Class Chart (Insecticides/Miticides, Fungicides, Herbicides and Plant Growth Regulators) for greenhouse and nursery production Vol. 13. www.ohp.com/tecnicalservive

65. Okigbo, R. N. (2004). A review of biological control methods for postharvest yams (Dioscorea spp.) in storage in South Eastern Nigeria. KMITL Science Technology Journal--4(1): 207-215.

66. Okwu, D. E. and Ukanwa, N. (2010a). Isolation and characterization of flavonoids chalcones and anthocyanidines from Bridelia ferruginea Benth. Der Chemica Sinica 1(2): 21 - 28.

67. Okwu, D. E. and Ukanwa, N. (2010b). Isolation, characterization and antibacterial activity screening of anthocyanidine glycoside from Alchornea cordifolia leaves. E-journal of Chemistry 7(1): 41 - 48.

68. on yam tuber dry rot disease. Annals Biol. Res. 2(2): 332-336.

69. Ononuju, C. C. and Kpadobi, U. C. (2008). Effect of plant leaf ash on the control of Meloidogyne incognita in soybean (Glycine max). Ind. J. Nematol. 38(1): 001-004.

70. Ononuju, C. C. and Nzenwa, P. O. (2011). Nematicidal effects of some plant extracts on egg hatchability and control of Meloidoyne spp. in cowpea (Vigna unguiculata L. Walp.). Afr. J. Plant Sci. 5(2): 176-182.

71. Ononuju, C.C. and Kpadobi, U. C. (2008). Effect of plant leaf ash on the control of Meloidogyne incognita in soybean (Glycine max (L.) Merrill. Ind. J. Nematol. 38(1): 09-14.

72. Opender, K. and Dhallwal, G. S. (2003). Phytochemical biopesticides Pp 104-108 http://book.google.com/phytochemical...

73. Oreskes, N. and Conway, E. M. (2010). Denial rides again; the revisionist attack on Rachel Carson. In: Merchants of doubt. NY, Bloomsbury Pp. 216-235.

74. Ott, K. C. (2015). Rotenone: a brief review of its chemistry, environmental fate, and the toxicity of rotenone formulations. www.newmexicotu.org/rotenone.sum...Accessed June 15, 2015

75. Pakela, Y. P. (2003). Characterization of Colletotrichum dematium causing anthracnose on cowpeas in South Africa. Upted.up.ac.za/thesis/.../etd.../01thesis.pdf

76. Pakela, Y.P. (2006). Interaction between Colletotrichum dematium and cowpea. www.dspace.up.ac.za...

77. Parveen, Z., Nawaz, S., Sidique, S and Shazad, K. (2013). Composition and antimicrobial activity of the essential oil from leaves of Curcumin longa. Ind. J. Pharm. Sci. 75(1): 117-122.

78. Passos, S. L., Barbosa L. C. A., Deminar, A. J., Alvaranger E. S., Da Silva, C. M.and Barreto R. W. (2012). Molecules 17: 11447-11455.

79. Pavia, C. S. Pierre, A. Nowakowsski, J. (2000). Antimicrobial activity of nicotine against a spectrum of bacterial and fungal pathogens. J Med. Microbial. 49: 674-678. 
80. Pevet, R. and Pont, V. (2003). Mode of action of Vitaceae stilbenes on fungal cells. In: Handbook of phytoalexin metabolism and action Pp 133-178. http;//www.books.google. ng>book... Accessed June 2, 2014.

81. Phosiso, S. (2011). Commercialization of plant biopesticides. A paper presented at the Africa Dryland Alliance for Pesticidal Plant Technologies (ADAPPT) IPM workshop Morogoro, Tanzania, Dec. 5-8, 2011.

82. Plant Profiler (2010). Mechanism of action of the bioactive products found in Vaccinium myrtillus (Bilberry). Sigmaadrich.com/life-science/nutrition-research/ learning-center/plant-profiler/vacciniummyrtillus.html

83. Plaper, A., Golob, M., Hafner, I., Obiak, M., Solmajer, T. and Jerala, R. (2003). Characterization of quercitin binding site on DNA gyrase. Biochem Biophs. Res. Omm. 306: 530-536.

84. Pronk M E J and Schefferlie, G. J. (2015). Toxicological evaluation certain verinary drug residues in food Tiabendzole (Thiabendazole). WHO food Additive Series 49, 2015.

85. Pscheidt, J. W. (2015). Fungicide theory of use and mode of action. Pacific NorthWest Plant Disease Handbook

86. Ragsdale, N.N (1994). Fungicides USDA-National Agricultural pesticide Impact Assessment Programme In: Encyclopedia of Agric. Sci. vol. 2, 445-453.

87. Sakata K., Aoki, K, Chang, C. F., Sakurai, A., Tamura, S. and Murakoshi, S. (1978). Stemospironine, a new insecticidal alkaloid of Stemona japonica Miq. Isolation, structural determination and activity. Agric. Biol. Chem. 42(2): 457-463.

88. Salvatone, M. J., King, A. B., Graham, A. C. Onishi, H. R., Bartizal, K. F., Abruzzo. G. K., C. J., Ramjit, H. G., Steven, M., Pitzenberger, S. M. and Witherup, K. M. (1998). Antimicrobial activity of Lonchocarpol A. J. Nat. Prod. 61: 640-642.

89. Schleier, K. K. and Peterson, R. K. D. (2011). Pyrethrins and Pyrethroids -- green trends in insect control: In: Lopaz, G and Fernandez-Bolanos, J. C. (eds). Royal Society of Chemistry No 11 RSC Publ. 2011. www.rsc.org

90. Schunemann, R., Knaaak, N., Fruza, L. M. (2014). Mode of action and specificity of Bacillus thuringiensis toxins in the control of caterpillars and stink bugs in soybean culture (Article ID 135675). ISRN Microbiol. 1-13.

91. Sherer, T. B., Betarbet, R., Testa, C.M. Seo, B. B. Richardson, J. R., Kim, J. H. Miller, G. R.., Yagi, T. Matsuno-Yagi, A and Greenamyre, J. T. (2003). Mechanism of Toxicity in Rotenone Models of Parkinson's Disease. www.ncbi.nim.nih.gov/pumed... Accessed July 2, 2015

92. Shimamura, T. Wei-Hua, Z nd Zhi-Qing, H. (2007). Mechanism of action and potential use of tea catechins as an anti-infective agent. Anti-Infective Agents Med. Chem. 4: 57-62.

93. Sho, M. M. E. (2015). Bangkok calachuche Adenium obesum (Forsk.) Roem \& Schult. The desert rose.

94. Silva-Aguayo, A. (2015). Botanical Insecticides. Radcliffe's IPM World Textbook. www.ipworld.umu.edu Accesed July 2, 2015

95. Stevenson, P. C., Belmann, T. K., Steven, R., and Veitch N. C. (2009). Bisdesmosidic saponins from Securidaca longepedunculata roots: evaluation of deterrency and toxicity to coleopteran storage pests. www.science.gov>topicpages>longepedunculata...[Abstr.] Accessed June 2, 2014.

96. STK (2013). Timorex-Gold (Melalueca alternifolia) The new generation of Bio-fungicides, full control of black sigatoka. Stockhon Group, pp 1-6. www.stockhon-ag.com Retrieved June 10, 2013.

97. Taiga, A. (2009). Efficacy of selected plant extracts in the control of fungal dry rot of white yam (Dioscorea rotundata) tubers in Kogi State. American-Eurasian J. Sust. Agric. 3: 310 - 313.

98. Taiga, A. (2011). Comparative studies on the efficacy of some selected fungicidal aqueous plant extracts on yam tuber dry rot disease. Annals of Biological Research 2(2): 332-336.

99. Tapwal, A. Singh, U., Da Silva, J. A. T., Singh, G. and Kumar, R. (2011). In vitro antagonism of Trichoderma viride against five phytopathogens. Pest Technol. 5(1): 59-62.

100. Tijjani, A., Ndukwe, I. G. and Ayo, R. C. (2011). Studies on the antibacterial activity of Adenium obesum (Apocynaceaee) stem bark. Continental J. microbial. 5(1): 12-17.

101. Tomlinson, S and Palombo, E. A. (2005). Characterization of antibacterial Australian medicinal plants by investigation of the mechanism of action and effects of interfering substances. J. Basic Microbiol. 45(5): 363-370.

102. Usman L. A. Hamid, A. A.., George, O.C., Ameen, O. M. Mohammad, N. O., Zubair, M. F. and Lawal, A. (2009). Chemical composition of rhizome essential oil of Curcumin longa growing in North central Nigeria. 4(2): 178-181.

103. Versani, M.A., Ahmed, S. K. Ikran, A., Ali, S. T., Yasmeen, K and Faizi, K. (2014). Chemical constituents and biological activity of Adenium obesum (Forsk.) Roem. Et Schult. Chemistry and biodiversity 11(12): 171-180. 
104. Wageningen University (2015). Pyrethrins for control of plant pathogens. www.wageningenur.nl/en/article/pyrethrins-for -control-of-plant-pathogens.htm

105. Wang, L.S, Stoner, G. D. (2008). Anthocyanins and their roles in cancer prevention. Cancer Lett. 269: 281-290.

106. Wink, M. (1998). Alkaloids: biochemistry, ecology and medicinal application. In: Roberts and Winks (Eds.), Plenum Press, NY, USA. Pp 301-326.

107. Wiratno, D. Taniwiryno, H. Vanden Berg, H, Riksen, JAC, Rietjens, IMCM, Djiwanti, S. R Kammenga, JE and Murk, A.J. (2009). Nematicidal activity of plant extracts against the root-knot nematode Meloidogyne incognita. The Open Nat. Prod. J. 2: 077-085.

108. Salami, O. A. and Popoola, O. O. (2007).Thermal control of some postharvest rot pathogens of Irish potato (Solanum tuberosum L.).Journal of Agricultural Sciences 52(1): 17-31.

109. Bandyopadhyay R., Kumar, M., Leslie, J. F.. (2007). Food Additives and Contaminants 24 (10): 11091114.

110.Okwu, D. E. and Njoku, E. E. (2009). Chemical composition and in vitro antifungal activity screening of seed and leaf extracts from Afromonium meleguata and Monodora myristica against Sclerotium rolfsii of cowpea. Pest Technogloy 3(1): 58 - 67.

111.Lamikanra, A.,Ogundani, A. O. and Ogunbamila, F. O. (1990). Antibacterial constituents of Alchornea cordifolia leaves.Phytotherapy Research 4: 98-100.

112.Enyiukwu, D. N. (2002). Effects of some plant extracts on the germination of cowpea (Vigna unguiculata (L) Wapl.) seeds and incidence of the seed-borne fungi. A Thesis submitted to the department of Plant Health Management, MOUAU, 2002.

113.Bill and Melinda Gates Foundation (2011). Helping poor farmers Helping Poor Farmers, Changes Needed to Feed 1 Billion Hungry. www.gatesfoundation.org/.../helping-por-farmers-changes-needed... 